\title{
SYNTHESIS, STRUCTURAL AND ANTIBACTERIAL STUDY OF NEW SILVER COMPLEX WITH 3-ACETYL-2H CHROMENE-2-ONE
}

\author{
Zulfiqar Ali ${ }^{1 *}$, Syeda Rubina Gilani², Habib Hussain ${ }^{2}$, Hajira Rehman ${ }^{3}$, Imdad Hussain ${ }^{2}$, Mazhar $^{*}$ \\ Amjad Gilani ${ }^{4}$ and Faiz Rabbani ${ }^{{ }^{*}}$ \\ ${ }^{1}$ Department of Chemistry, Lahore Garrison University, DHA Lahore, Pakistan \\ ${ }^{2}$ Department of Chemistry, University of Engineering \& Technology, 54890, Lahore, Pakistan \\ ${ }^{3}$ Institute of Chemistry, University of Punjab, 54590, Lahore, Pakistan \\ ${ }^{4}$ Department of Chemical Engineering, COMSATS Institute of Information Technology \\ Defence Road, Off-Raiwind Road, Lahore-Pakistan \\ ${ }^{5}$ Department of Environmental Sciences, COMSATS Institute of Information Technology, \\ Mailsi Road, Off Multan Road, Vehari, 61100, Pakistan
}

(Received August 11, 2015; revised June 23, 2016)

\begin{abstract}
A new silver complex $\left[\mathrm{Ag}\left(\mathrm{C}_{11} \mathrm{H}_{8} \mathrm{O}_{3}\right)_{2}\right] \mathrm{NO}_{3}$ was synthesized by the reaction of silver nitrate and coumarin based ligand (3-acetyl- $2 H$-chromene-2-one) through solution method. The product was characterized using different analytical techniques like melting point, Infrared spectroscopy, Raman spectroscopy, powder X-ray diffraction, thermogravimetric analysis, scanning electron microscopy, atomic absorption spectroscopy and mass spectrometry. An antibacterial study of the complex was also studied for its possible use in medical treatment.
\end{abstract}

KEY WORDS: Silver complex, Acetyl coumarin, Vibrational analysis, Antibacterial study

\section{INTRODUCTION}

Coumarin and its derivatives have been isolated from woodruff vanilla grass, sweet grass, sweet woodruff, and deer's tongue. Further coumarin and its annealated derivatives are reported to possess significant antibacterial [1], coronary dilatory [2] and hypothermia activities [3]. Therefore, it became of interest to synthesize new derivatives of these systems of expected biological activities. Similarly different metal complexes of coumarin and their derivatives also exhibited biological activity against various pathogens.

Biological activity of a complex is not based only organic ligand but it is also affected by the oxidation state of the metal. These properties provide a versatile platform for drug design that is now being exploited in several areas. For centuries, silver compounds have been known to possess interesting biological properties like antibacterial properties [4-7]. Also, they were popular remedies for tetanus and rheumatism in the 19th century and for colds and gonorrhea before the advent of antibiotics in the early part of the 20th century [8]. Additionally, silver compounds used for treating mental illness, epilepsy, and nicotine addiction [9, 10]. Furthermore, they have re-emerged as a viable treatment option for infections encountered in burns, open wounds, and chronic ulcers [11-14].

In this study, acetyl coumarin was synthesized and studied against various gram +ve and gram -ve bacteria. In order to study the affect of silver metal on above mentioned organic ligand and its activity is studied against different bacterial strains.

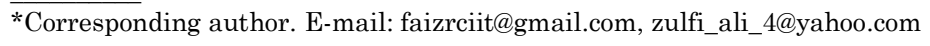




\section{EXPERIMENTAL}

Synthesis of silver complex

A solution of $1 \mathrm{mmol}(0.188 \mathrm{~g}) 3$-acetyl-2H-chromene-2-one and $1 \mathrm{mmol}(0.04 \mathrm{~g})$ sodium hydroxide in $10 \mathrm{~mL}$ water was added to a solution of $1 \mathrm{mmol}(0.108 \mathrm{~g})$ silver(I) nitrate in $10 \mathrm{~mL}$ water and stirred over a period of $15 \mathrm{~min}$ at room temperature. The coloured precipitates are formed which were then filtered off, washed with cold water and ethanol and dried in vacuum over calcium chloride at room temperature.

Melting point was determined using Scientific Electrothermal melting point apparatus (1401Q). The vibrational studies of the complex were performed on Nicolet 6700P Infrared Spectrometer (USA). The structural parameters were calculated using PANalytical (X'Pert $\mathrm{PRO}$ ) diffractometer (using $\mathrm{Cu}-\mathrm{K} \alpha$ radiation). Thermal measurements were performed on TGA/DSC (Q600) purging nitrogen gas using alumina crucible. Mass spectrum of complex was obtained on Mass spectrometer (1200 series, Agilent technology, with scanning speed up to $5250 \mu / \mathrm{s}$, quadrupole, mass range $\mathrm{m} / \mathrm{z}=2-3000$ ) while AAS experiments were performed on Atomic Absorption Spectrometer (Varian AA240). Metal-ligand vibrational bands were studied on Raman spectrometers (Renishaw 1000). SEM micrographs were obtained on S3700N (HITACHI), Japan.

\section{RESULTS AND DISCUSSION}

\section{Melting point study}

The melting point of the complex was performed using melting point apparatus. The results showed that melting point of silver complex was not sharp but in a range of $345-355^{\circ} \mathrm{C}$ which is also not comparable with that of reactants, i.e. $\operatorname{AgNO}_{3}\left(212^{\circ} \mathrm{C}\right)$ and 3-acetyl-2H-chromene-2one $\left(120^{\circ} \mathrm{C}\right)$ which help to conclude that reaction was completed and a new phase was obtained.

\section{Infrared studies}

The presence of ligand was verified by IR study of the synthesized complex as shown in Figure 1. The stretching vibration of C-H corresponding to alkene is observed at $3030 \mathrm{~cm}^{-1}$ [15]. While the stretching bands observed at $2935 \mathrm{~cm}^{-1}$ and $2980 \mathrm{~cm}^{-1}$ are due to $\mathrm{C}-\mathrm{H}$ (- $\mathrm{CH}_{3}$ group) [16] which were further verified by symmetrical deformation at $1415 \mathrm{~cm}^{-1}$ and $1552 \mathrm{~cm}^{-1}$ in both IR and Raman anaylsis. An overtone band of $974 \mathrm{~cm}^{-1}$ appeared at $1937 \mathrm{~cm}^{-1}$. The vibration at 1726 $\mathrm{cm}^{-1}$ is assigned to stretching bands of $\mathrm{C}=\mathrm{O}[17,18]$ which is further confirmed by Raman measurement at $1675 \mathrm{~cm}^{-1}$ and $1745 \mathrm{~cm}^{-1}$ [19]. The stretching vibration of $\mathrm{C}=\mathrm{C}$ (benzene ring) appeared at $1609 \mathrm{~cm}^{-1}$. The bending vibration of C-H (alkane) is shown at $1452 \mathrm{~cm}^{-1}$ and that for alkene with out of plane is also shown in the range of $1000 \mathrm{~cm}^{-1}$ to $650 \mathrm{~cm}^{-1}$. The vibrations appeared in the range of $1300 \mathrm{~cm}^{-1}$ to $1000 \mathrm{~cm}^{-1}$ corresponds to C-O-C [20,21]. It is reported that vibrational bands of Ag-O are lying in the range of $253-205 \mathrm{~cm}^{-1}[22,23]$ which is out of limits of IR range. The IR spectrum shows that there is no band assigned to $-\mathrm{OH}$ which clue the absence of water molecules in the synthesized product. The bands observed in the range of IR region (1609-637 $\mathrm{cm}^{-1}$ ) which are correlated to C-C stretching vibration and comparable with literature [24]. In this study, the vibrations observed at in the region of $1620-600 \mathrm{~cm}^{-1}$ in both IR and Raman measurements are due to the ring vibrations.

\section{Raman analysis}

The most significant peaks of silver lattice, i.e. at $95 \mathrm{~cm}^{-1}$ and $146 \mathrm{~cm}^{-1}$ cannot be observed in Raman pattern [25] which indicates the absence of elemental silver in the product. The peaks observed in the range of $900-1100 \mathrm{~cm}^{-1}$ are attributed to the Ag-O stretching frequencies [26]. 
Synthesis and structural study and of new silver complex with 3-acetyl- $2 H$ chromene-2-one 405

The raman vibration at $950 \mathrm{~cm}^{-1}$ are commonly related to chemisorbed oxygen species [27-29] as shown in Figure 2.

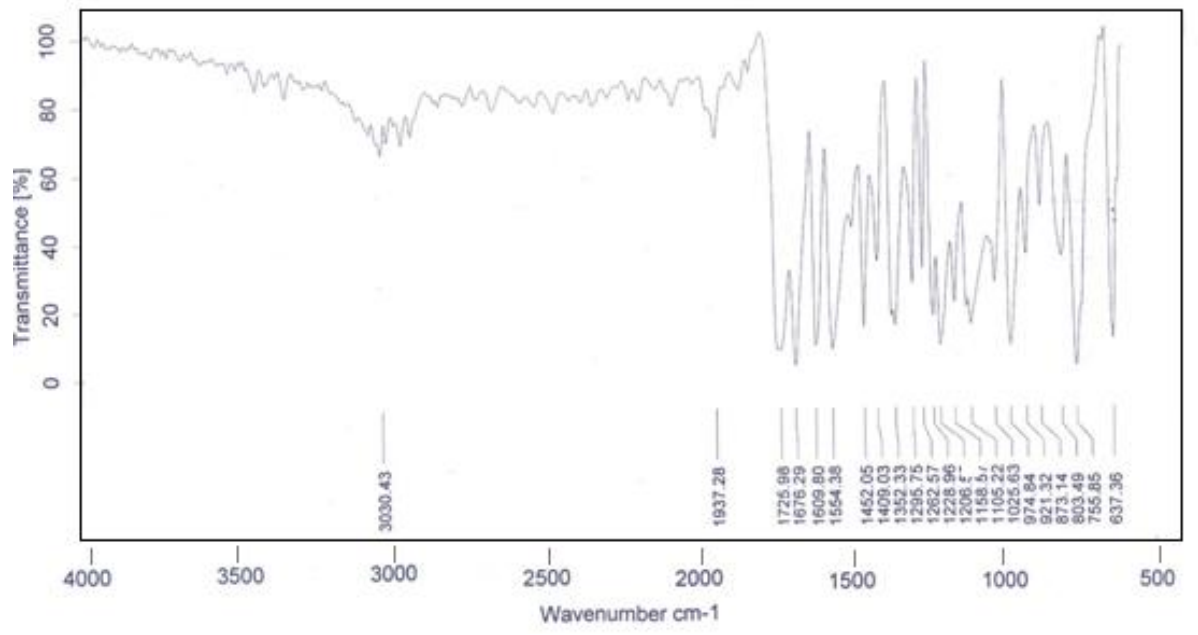

Figure 1. IR spectra of silver complex with 3-acetyl-2H-chromene-2-one

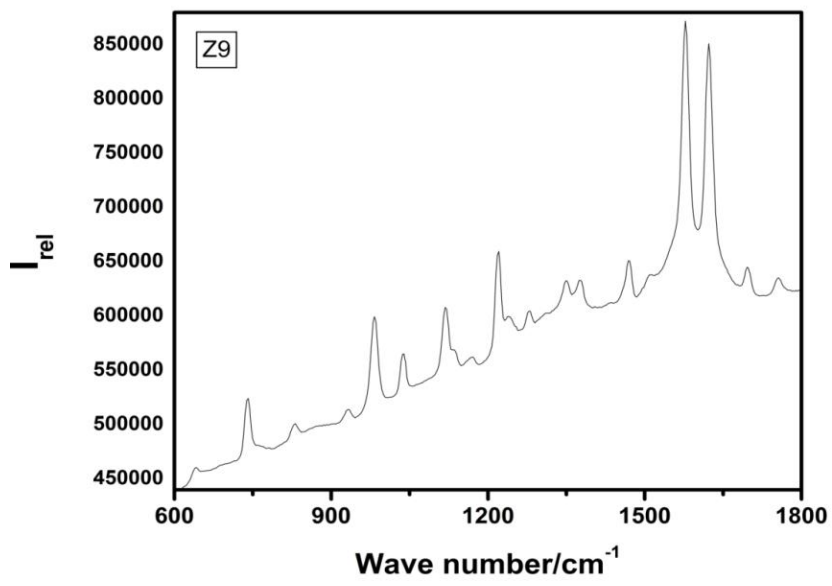

Figure 2. Raman spectrum of silver complex.

\section{Powder X-ray diffraction analysis}

The X-ray powder diffraction pattern of silver complex with 3-acetyl- $2 H$-chromene-2-one was obtained on X-ray powder diffractometer under $45 \mathrm{kV} / 40 \mathrm{~mA}$ X-ray, $2 \theta /{ }^{\circ}$ scanning mode, fixed monocharomator and with a range from $2 \theta /^{\circ}=10$ to 90 with a step of 0.03 degree for a period of $30 \mathrm{~min}$ is shown in Figure 3. Powder X-ray diffraction results of synthesized product was obtained on powder diffractometer for half an hour with a step of $0.03^{\circ}$ along fixed monochromator for $2 \theta$ value $\left(10^{\circ}-90^{\circ}\right)$. A total eight peaks were targeted and calculated their miller indices shown in Table 1.

Bull. Chem. Soc. Ethiop. 2016, 30(3) 


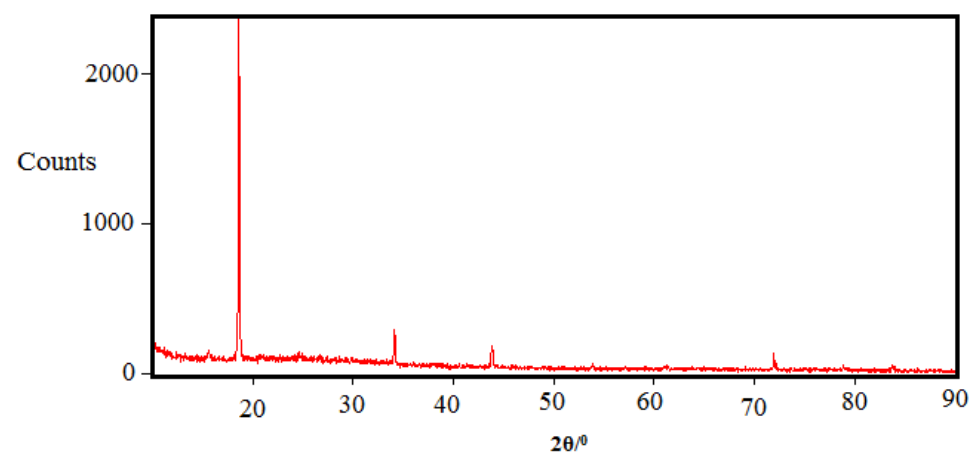

Figure 3. XRD pattern of silver complex with 3-acetyl- $2 H$-chromene-2-one.

Table 1. Calculation of miller indices through XRD diffraction pattern.

\begin{tabular}{|c|c|c|c|c|c|c|c|}
\hline $2 \theta /{ }^{0}$ & $\theta /{ }^{0}$ & $\operatorname{Sin}^{2} \theta$ & $1 \times \operatorname{Sin}^{2} \theta / \operatorname{Sin}^{2} \theta_{\min }$ & $2 \times \operatorname{Sin}^{2} \theta / \operatorname{Sin}^{2} \theta_{\min }$ & $3 \times \operatorname{Sin}^{2} \theta / \operatorname{Sin}^{2} \theta_{\min }$ & $\begin{array}{c}\text { Whole } \\
\text { integers }\end{array}$ & $h k l$ \\
\hline 15.6758 & 7.8379 & 0.01859 & 1 & 2 & 3 & 3 & 111 \\
\hline 18.6587 & 9.3293 & 0.02627 & 1.4131 & 2.8262 & 4.2393 & 4 & 211 \\
\hline 34.0831 & 17.0415 & 0.08588 & 4.6196 & 9.2392 & 13.8588 & 14 & 321 \\
\hline 42.7785 & 21.3892 & 0.13300 & 7.1543 & 14.3086 & 21.4629 & 21 & 421 \\
\hline 53.8968 & 26.9484 & 0.20537 & 11.0473 & 22.0946 & 33.1419 & 33 & 522 \\
\hline 71.1132 & 35.5566 & 0.33815 & 18.1898 & 36.3796 & 54.5694 & 54 & 721 \\
\hline 79.7329 & 39.8664 & 0.41088 & 22.1022 & 44.2044 & 66.3066 & 66 & 811 \\
\hline 85.5229 & 42.7614 & 0.46096 & 24.7961 & 49.5922 & 74.3883 & 74 & 831 \\
\hline
\end{tabular}

To observe the novelty of synthesized complex, a comparison was made between the calculated pattern and reported patterns using peak search method. The measurement showed that peaks present at $15.6758,18.6587,34.0831,42.7785,53.8968,71.1132,79.7329,85.5229$ $\left(2 \theta /{ }^{\circ}\right)$ exhibit miller indices as $111,211,321,421,522,721,811,831$ respectively that confirm the uniqueness of the pattern. The material parameters like particle size, dislocation line density and strain of the synthesized product were also calculated as shown in Table 2.

Table 2. Calculation of material parameters of $\mathrm{Ag}$ complex.

\begin{tabular}{|c|c|c|c|c|c|c|}
\hline $2 \theta /{ }^{0}$ & $\mathrm{FWHM} / 2 \theta^{\circ}$ & Intensity/counts & d-spacing/Å & Grain size (D)/nm & \begin{tabular}{|c|} 
Dislocation \\
Density $(\delta) /$ lines $/ \mathrm{cm}^{-2}$
\end{tabular} & $\begin{array}{l}\text { Strain (S)/ } \\
\text { lines }^{-2} \mathrm{~cm}^{-4}\end{array}$ \\
\hline 15.6758 & 0.4723 & 1.75 & 5.65324 & 2.9639 & 0.11383 & 0.1169 \\
\hline 18.6587 & 0.1181 & 100.00 & 4.75565 & 11.9016 & 0.00705 & 0.0291 \\
\hline 34.0831 & 0.1476 & 10.14 & 2.63060 & 9.8266 & 0.01035 & 0.0352 \\
\hline 42.7785 & 0.1771 & 5.73 & 2.06789 & 9.0328 & 0.01225 & 0.0383 \\
\hline 53.8968 & 0.2362 & 1.08 & 1.70114 & 1.7449 & 0.32844 & 0.1986 \\
\hline 71.1132 & 0.1771 & 3.17 & 1.31344 & 11.8305 & 0.00714 & 0.0293 \\
\hline 79.7329 & 0.3542 & 0.60 & 1.21288 & 5.1013 & 0.03842 & 0.0679 \\
\hline 85.5229 & 0.4320 & 0.78 & 1.15351 & 6.4310 & 0.02417 & 0.0539 \\
\hline
\end{tabular}

Table 2 showed that the grain size was found to be in the range of $11.9016 \mathrm{~nm}$ at $29 /^{\circ}=$ 18.65 to $2.9639 \mathrm{~nm}$ at $2 \theta /^{\circ}=15.67$. Dislocation density values are smaller which indicate the purity of a substance. Variations in different structural parameters are shown in the Figure 4. 

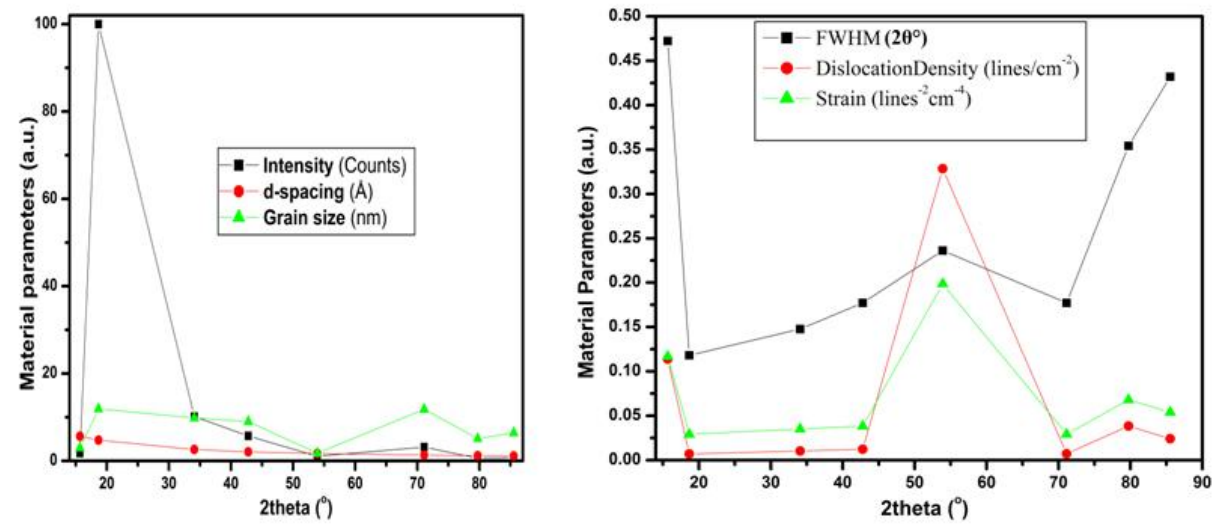

Figure 4. Graphical relations between $2 \theta^{\circ}$ and material parameters.

Thermal gravimetric analysis

The sample was run on thermogravimetric analyzer (TGA/DSC-Q600) and obtained decomposition pattern as shown in Figure 5.

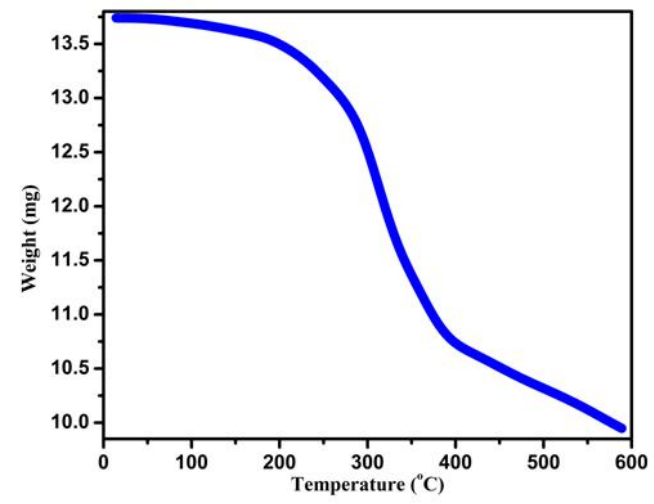

Figure 5. TGA curve of Ag metal with 3-acetyl-2H-chromene-2-one

Thermal analysis showed a first weight loss with fast decomposition from $200{ }^{\circ} \mathrm{C}$ to $380{ }^{\circ} \mathrm{C}$ followed by second weight loss in the range of $400{ }^{\circ} \mathrm{C}$ to $600{ }^{\circ} \mathrm{C}$. In $1^{\text {st }}$ weight loss, one of the two ligands attached to the silver metal atom may be removed and in the $2^{\text {nd }}$ weight loss, second or residual ligand is expected to remove. The remaining residue was undetermined.

Electrospray ionization-mass spectrum (ESI-MS)

Mass spectrum was recorded on ESI-MS spectrometer to ensure the proposed structure of the product as shown in Figure 6.

Bull. Chem. Soc. Ethiop. 2016, 30(3) 


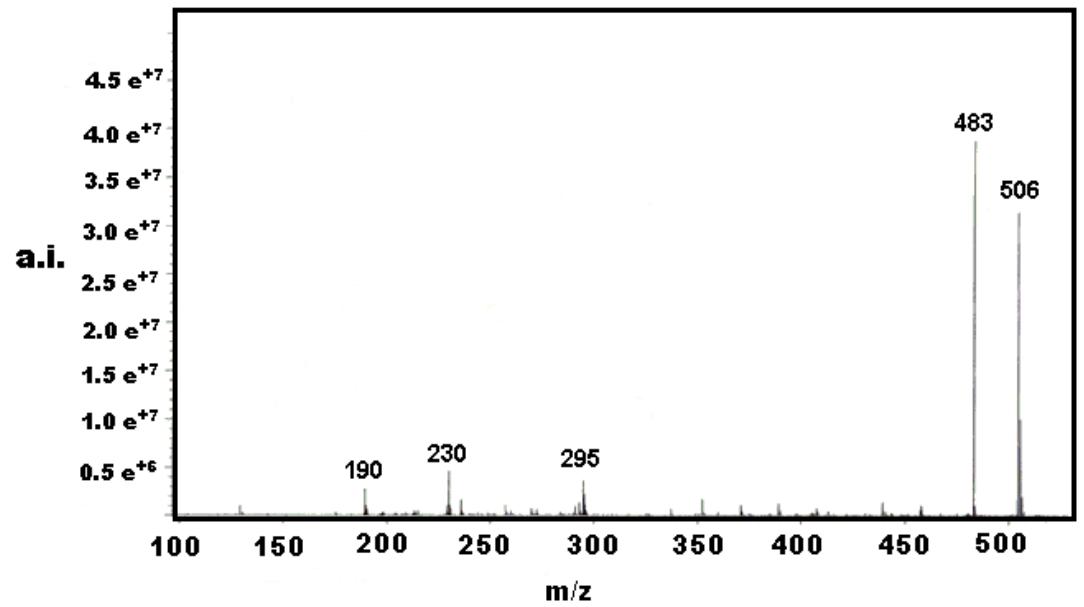

Figure 6. Electrospray ionization-mass spectrum (ESI-MS) of silver complex.

A molecular ion peak was observed at $\mathrm{m} / \mathrm{z} 483.4$ which was co-related to ionic specie $\left[\mathrm{C}_{20} \mathrm{H}_{14} \mathrm{AgO}_{6}+\mathrm{H}\right]^{+}$. Some extra peaks were also found due to impurities or due to by-product formed during decomposition. A sharp peak of the sodium salt of the complex $\left[\mathrm{C}_{20} \mathrm{H}_{14} \mathrm{AgO}_{6}+\right.$ $\mathrm{Na}]^{+}$was found at $\mathrm{m} / \mathrm{z}$ 506.0. Thus proposed structure of product was confirmed from molecular ion peak $[\mathrm{M}+1]^{+}$in the spectra.

Atomic absorption measurement

Atomic absorption measurement was performed to find the metal to ligand ratio (by weight \%) in the synthesized product. The sample solutions and standard solutions were prepared as shown in as shown in Table 3.

Table 3. Concentration of silver metal complexes obtained experimentally.

\begin{tabular}{|c|c|c|}
\hline S. No. & Sample description & Amount of metal estimated by AAS (ppm) \\
\hline 1 & Sample 1 & 27.2 \\
\hline 2 & Sample 2 & 18.2 \\
\hline 3 & Sample 3 & 24.2 \\
\hline
\end{tabular}

To determine an exact formula, experimental result was compared with theoretical one. An atomic absorption analysis shows that metal/ligand (wight \%) in the synthesized complex is $24.2 \%$ which is comparable with the theoretical one $(22.3 \%)$ of complex as shown in Table 4.

Table 4. Expected metal to ligand ratio.

\begin{tabular}{|c|c|c|c|c|}
\hline S. No. & Ag metal & Ligand & Total weight & Metal (\%) \\
\hline 1 & 1 & 1 & 296 & 36.4 \\
\hline 2 & 1 & 2 & 483 & 22.3 \\
\hline 3 & 1 & 3 & 671 & 16.1 \\
\hline 4 & 1 & 4 & 860 & 12.5 \\
\hline 5 & 1 & 5 & 1048 & 10.3 \\
\hline
\end{tabular}


Synthesis and structural study and of new silver complex with 3-acetyl- $2 H$ chromene-2-one 409

The result shows that metal/ligand is $1: 2$ hence the proposed formula of the complex is as $\mathrm{Ag}\left(\mathrm{C}_{11} \mathrm{H}_{8} \mathrm{O}_{3}\right)_{2}$.

\section{Scanning electron microscopic (SEM) studies}

SEM micrographs were obtained in the range of $50 \mu \mathrm{m}$ to $5 \mu \mathrm{m}$ using Variable Pressure Scanning Electron Microscope (TESCAN Vega LMU) as shown in Figure.7.

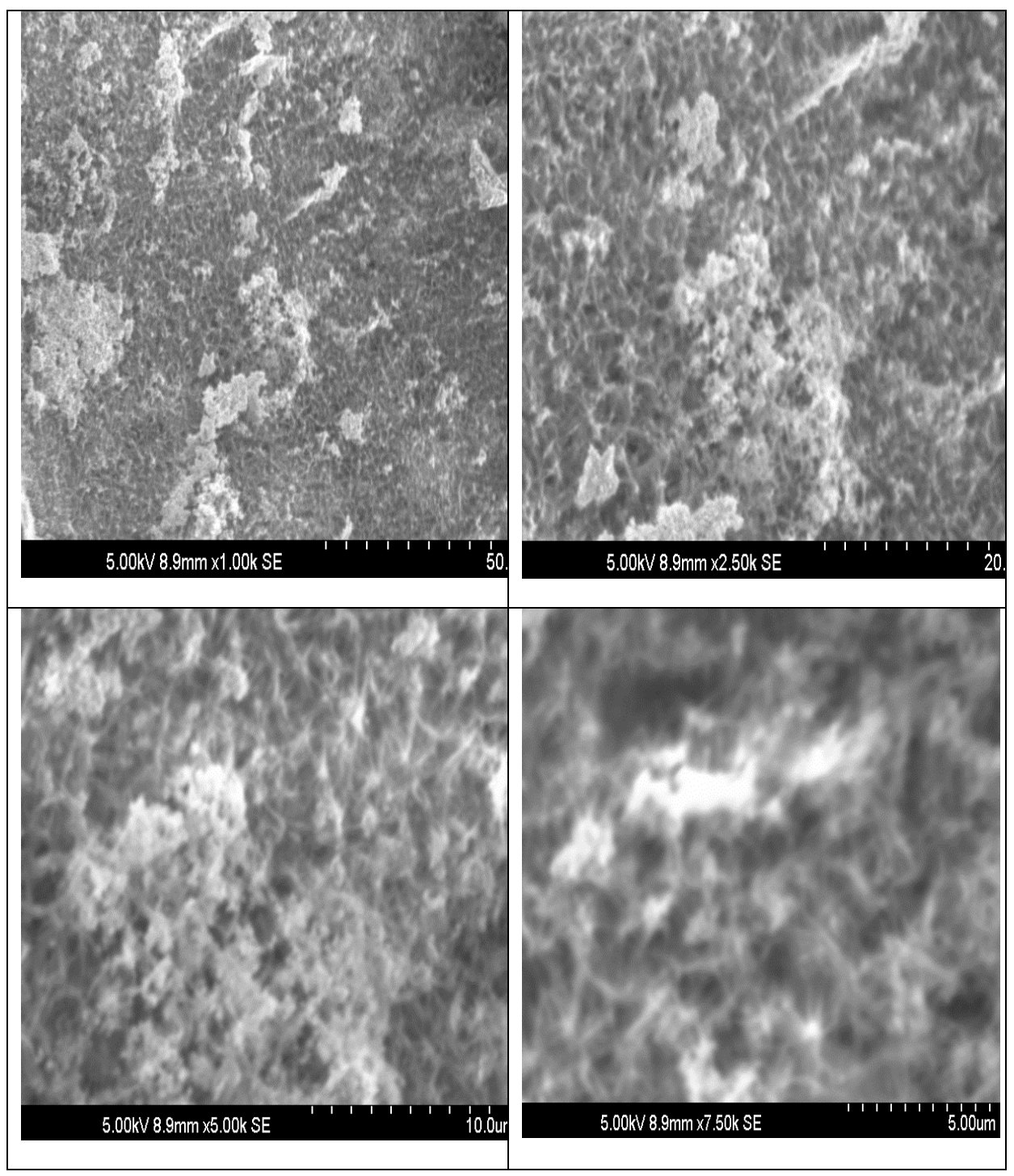

Figure 7. SEM micrographs of silver complex (with resolution $5 \mu \mathrm{m}$ to $50 \mu \mathrm{m}$ ). 
The results show that the particles of the synthesized complex exist in form of cluster having smooth surface. Secondary electron images of new silver complex show that surface morphology of product is in the range of range of micron. Spatial distribution of the particles in the material shows that they are homogenously, equally and well dispersed throughout the bulk material. The more bright regions might be due to direct interaction of light with particles.

\section{Antibacterial activity of silver complexes}

Different gram positive and gram negative bacterial strain experiments were performed using ligand and silver complex as shown in Table 5.

Table 5. Antibacterial study of silver complex.

\begin{tabular}{|l|c|c|c|c|c|c|}
\hline \multirow{2}{*}{$\begin{array}{l}\text { Name of } \\
\text { compound }\end{array}$} & \multicolumn{4}{|c|}{ Diameter of inhibition zone (mm) } \\
\cline { 2 - 7 } & \multicolumn{3}{|c|}{ Gram positive } & \multicolumn{3}{c|}{ Gram negative } \\
\cline { 2 - 7 } & S. aureus & B. subtilis & MRSA & E. coli & P. auruginosa & S. typhi \\
\hline Ligand & 28 & 18 & - & 17 & - & - \\
\hline Ag-complex & 28 & 11 & 15 & 12 & - & - \\
\hline
\end{tabular}

Note: Mean inhibition zones are measured in $\mathrm{mm}$.

The complex was very effective against S. aureus, MRSA, E. Coli and B. Subtilis and reluctant their growth to a greater extent but ligand did not diffident the growth of MRSA. Both ligand and product could not inhibit the growth of $P$. auruginosa and $S$. typhi. It is cleared from above discussion that an activity of the ligand (3-acetylcoumarin) has been enhanced with an addition of Ag-metal atom.

The MIC results of silver complex against these bacteria are shown in Table 6. An experimental value using ligand is $20 \mu \mathrm{g}$ MIC value for $S$. aureus, $15 \mu \mathrm{g}$ for B. subtilis and 10 $\mu \mathrm{g}$ for $E$. coli. The lower MIC values for silver complex gave clue that activity of the product is increase by silver against pathogens.

Table 6. MIC results of silver metal complexes against these bacteria

\begin{tabular}{|l|c|c|c|c|c|c|}
\hline \multirow{2}{*}{$\begin{array}{l}\text { Name of } \\
\text { compound }\end{array}$} & \multicolumn{5}{|c|}{ Diameter of inhibition zone (mm) } \\
\cline { 2 - 7 } & \multicolumn{3}{|c|}{ Gram positive } & \multicolumn{3}{c|}{ Gram negative } \\
\cline { 2 - 7 } & S. aureus & Bacillus subtilis & MRSA & E. coli & P. auruginosa & S. typhi \\
\hline Ligand & $20 \mu \mathrm{g}$ & $15 \mu \mathrm{g}$ & - & $10 \mu \mathrm{g}$ & - & - \\
\hline Ag-complex & $20 \mu \mathrm{g}$ & $10 \mu \mathrm{g}$ & $10 \mu \mathrm{g}$ & $5 \mu \mathrm{g}$ & - & - \\
\hline
\end{tabular}

\section{CONCLUSION}

A new complex $\left[\mathrm{Ag}\left(\mathrm{C}_{11} \mathrm{H}_{8} \mathrm{O}_{3}\right)_{2}\right] \mathrm{NO}_{3}$ is obtained. The structural studies of the complex were done using X-ray measurement. The material parameters of complex like crystallite size, dislocation line density, stress have been calculated. Results show that activity of ligand has been increased after the complex formation.

\section{ACKNOWLEDGEMENT}

Zulfiqar Ali greatfully acknowledges Higher Education Commission (HEC) of Pakistan for providing financial support under Indigenous $5000 \mathrm{PhD}$ Fellowship Programme. 
Synthesis and structural study and of new silver complex with 3-acetyl- $2 H$ chromene-2-one 411

\section{REFERENCES}

1. Cingolani, G.M.; Gaultieri F.; Pigini, M. J. Med. Chem. 1969, 12, 531.

2. Muthur, C.N.; Mitra, C.R.; Krishnaswamy, N.R.; Kulshreshtha, R.K.; Arora, R.B. Arch. Int. Pharm. 1965, 153, 218.

3. Kitagawa, H.; Iwaki, R. Yakagaku Zasshi 1959, 79, 639.

4. Wright, J.B.; Hansen, D.L.; Burrell, R.E. Wounds 1998, 10, 179.

5. Richard, J.W.; Spencer, B.A.; McCoy, L.F.; Carina, E.; Washington, J.; Edgar, P. J. Burns Surg. Wound Care 2002, 1, 11.

6. Russell, A.D.; Hugo, W.B. Prog. Med. Chem. 1994, 31, 351.

7. Fu-Ren, F.; Allen, J.F. J. Phys. Chem. B 2002, 106, 279.

8. Mirsattari, S.M.; Hammond, R.R.; Sharpe, M.D.; Leung, F.Y.; Young, G.B. Neurology 2004, 62, 1408.

9. Alidaee, M.R.; Taheri, A.; Mansoori, P.; Ghodsi, S.Z. Br. J. Dermatol. 2005, 153, 521.

10. Tanweer, F.; Hanif, J. Clin. Otolaryngol. 2008, 33, 503.

11. Lansdown, B.G.A. The role of silver, European Tissue Repair Society Bulletin in press.

12. Wright, J.B.; Lam, K.; Buret, A.G.; Olson, M.E.; Burrell, R.E. Wound Repair Regen. 2002, $10,141$.

13. Paddock, H.N.; Schultz, G.S.; Perrin, K.J. Clinical assessment of silver-coated antimicrobial dressing on MMPs and cytokine levels in non-healing wounds in Proceedings of the Annual Meeting of the Wound Healing Society, Baltimore, USA; 2002.

14. Wu, H.; Yuan, J.; Bai, Y.; Pan, G.; Wang, H.; Kong, J.; Fan, X.; Liu, H. Dalton Trans. 2012, 41,8829 .

15. Krishnakumar, V.; John Xavier, R. Indian J. Pure Appl. Phys. 2003, 41, 597.

16. Bunce, S.J.; Edwards, H.G.; Johnson, A.F.; Lewise, I.R.; Turner, P.H. Spectrochim. Acta A 1993, 49, 775.

17. Smith, B. Infrared Spectral Interpretaion, A Systematic Approach, CRC Press: Washington; 1999.

18. Peesole, R.L.; Shield, L.D.; McWillam, I.C. Modern Methods of Chemical Analysis, Wiley: New York; 1976.

19. Bahgat, K. Cent. Eur. J. Chem. 2006, 4, 773.

20. Pavia, D.L.; Lampman, G.M.; Kriz, G.S.; Vyvyan, J.R. Introduction to Spectroscopy, 4th ed., Brooks/Cole: USA; 2008.

21. M. B. Halli, P. Vithal Reddy, Sumathi R. B and Basavaraja. A, Der Pharma Chemica 2012 , 4, 1214

22. Morzyk-Ociepa, B; Michalska, D. Spectrochem. Acta A: Mol. Biomol. Spectros. 1999, 55, 2671.

23. Creaven, B.S.; Egan, D.A.; Kavanagh, K.; McCann, M.; Noble, A.; Thati, B.; Walsh, M. Inorg. Chim. Acta 2006, 359, 3976.

24. Krishnakumar, V.; Xavier, R.J. Indian J. Pure Appl. Phys. 2003, 41, 95

25. Bosnick, K.A. Raman studies of mass-selected metal clusters, $P h D$ Thesis, University of Toronto, Canada; 2000.

26. Martina, I.; Wiesinger, R.; Jembrih-Simbürger, D.; Schreiner, M. Micro-raman characterisation of silver corrosion products: Instrumental set up and reference database, ePS 2012, 9, 1.

27. Long, D.A. Infrared and Raman Characteristic Group Frequencies: Tables and Charts George Socrates, 3rd ed., John Wiley and Sons: Chichester; 2001.

28. Nakamoto, K. Infrared and Raman Spectra of Inorganic and Coordination Compounds. Part A: Theory and Applications in Inorganic Chemistry, 6th ed., John Wiley and Sons: New York; 2009.

29. Wang, C.B.; Deo, G.; Wachs, I.E. J. Phys. Chem. B 1999, 103, 5645. 